\title{
Surfaces
}

\section{CORPUS EPOCHALIS. MYSTICISM, BODY, HISTORY}

\section{Calin Mihailescu}

Volume 1, 1991

URI : https://id.erudit.org/iderudit/1065257ar

DOI : https://doi.org/10.7202/1065257ar

Aller au sommaire du numéro

Éditeur(s)

Les Presses de l’Université de Montréal

ISSN

1188-2492 (imprimé)

1200-5320 (numérique)

Découvrir la revue

Citer cet article

Mihailescu, C. (1991). CORPUS EPOCHALIS. MYSTICISM, BODY, HISTORY.

Surfaces, 1. https://doi.org/10.7202/1065257ar
Résumé de l'article

Le discours du corps et de l'histoire dans la tradition mystique,

particulièrement Pascal. De Certeau à propos de l'histoire, Deleuze et Guattari à propos du corps. 


\title{
CORPUS EPOCHALIS
}

\section{MYSTICISM, BODY, HISTORY}

Calin Mihailescu

\begin{abstract}
The discourse of the body and history in the mystical tradition, especially Pascal. De Certeau on the history of Mysticism, Deleuze and Guattari on the body.

RÉSUMÉ

Le discours du corps et de l'histoire dans la tradition mystique, particulièrement Pascal. De Certeau à propos de l'histoire, Deleuze et Guattari à propos du corps.
\end{abstract}

In the attempt to revisit Christian mystical literature today, one comes to the point where an apparently misplaced question has to be addressed: how are we to think of the bodily conditions under which one can subsist beyond the impact of time? This question appears to provoke either nonsensical or ironic answers, because mysticism is usually interpreted within either a (neo) Platonic or a Christian-eschatological hermeneutic framework.

For Plato, and later for the middle Platonists (Celsus, Albinus), and neoPlatonists (Plotinus, Proclus), the material body is relegated to time, and death is perceived as a moment of eliberation from accidental impositions. To reach a level of changelessness means to rid of time and body, that is, to come to the knowledge that the soul does not die and does not mingle with the body (Phaedo 78c). There exists a certain tendency to overstate the influence of neo-Platonic thought on Christian mysticism (especially on such seminal figures as Pseudo-Dionysius Areopagita (V-VI-th century), Meister 
Eckhart (XIII-XIV) and Saint John of the Cross (XVI)). In this light, the desire of the mystics to leave this world, to "get lost" (Weltlossigkeit) is understood as a seemingly Platonic disregard of materiality. The following step - -- the inclusion of mysticism in the great tradition of Western "idealist" metaphysics -- is easy to make, and the mystics have often been called to justify the grand theories which will stay in power until the critiques of Nietzsche and Heidegger.

On the other hand, Christian eschatology, a way of thinking already historicized by the end of the New Testament, provides a powerful framework that may include and disposses mystical thought of its irreductible particularities. The "immortality of the body" in eschatological thought amounts to mortification, with the difference that one does not find an Egyptian mummy in a "post-apocalyptic pyramid": here the body is mortified by omission. In Christian terms, an "eschatological body" is utter nonsense. As the Christian apocalyptic thought focuses on the moral aspects of the Last Judgment, the body is relegated to a space that is absent from Christian discourse. For Bultmann this process amounts to a major

displacement in the history of Christian thought: the eschatological otherworldly substitutes the un-worldly from which Christ emerges. The real urgency imposed by Christ's presence and absence is traded for a "delayed urgency," a feeling common to all members of the race. The concept of Christian history emerges as the way toward the second coming and the Last Judgment, and in this historicization the experience of the individual, of his body, of utter urgency, is marginalized or lost.

Christian mysticism stands for the values displaced by historicization. For the mystics, death is always around the corner: not the death threatening a people, announced by the Vetero-Testamentary prophets, not the death of the human race, but the death of the mystic, "my death". For the mystics, death is the extase matérielle: matter steps outside of matter but not in the concept. The mystical recovers the materiality of nothingness, outside any possible distinction between natural and supernatural, however these terms are defined. The mystic is the one who can unashamedly say: I die, and come back and say it again.

One of the consequences of the opposition between what is roughly differentiated here as Christian mysticism and Christian eschatology lies in that a historical discourse on mysticism can be but a falsification of its object. One feels compelled to address the concepts of 'body' and 'history' in a way that attempts to overlook historical discoursing by suggesting a nonhistorical "temporal frame".

Our story begins with St. Francis of Asissi's showing of the godly scars and ends, more than four centuries later, with the concealment of the "divine wounds". Pascal's heritage of struggle and complications, of dialectical tension, is with us, and our critical thining tries to reinvoke the existence of 
a natural body not devoid of spirituality, while St. Francis's heritage, too essentially simple, is lost somewhere, beneath the cloth of our "delicacy."

\section{While in his cell on Mt Averno in 1224, Francis of Asissi}

was visited by a seraph in the likeness of Christ crucified, who, embracing him, produced upon his hands, feet, and side five wounds. The stigmata have been seen (by Pope Alexander IV among other less illustrious Christians), "documented" by Tommaso of Celano in both of his biographies of St Francis, and made the object of a legendary reverence for the founder of the Franciscan order. The stigmata provided the Franciscans with something no other religious order could claim: for neither St. Benedict nor St. Bernard nor Francis' contemporary, St. Dominic, could prove that they had conformed their lives to Christ to the point of imitating the scars of the Passion. Far from being the only or the first stigmatic recognized by the Church, Francis is the most famous. His example triggered a true epidemic that swept across Europe for centuries. So far, more than 300 persons have been identified as having been stigmatized, sixty of whom were declared saints or blessed in the Roman Catholic Church, which, routinely very careful when it came to sanctifications, could not help but sanction the validating proof of the stigmata.

The story of the paramount mark of the imitation of Christ: the scars of Passion sanction lived experience according to true faith. As the body of the faithful receives the sign of grace, the boon of the elect, an inquiry into the secular rationalizations of this experience proves unrewarding. On the one hand, there is the explanation which traces the origins of the wounds back to an act of self-infliction in a state of exaltation, epilepsy, etc. (often associated with female frailty.) On the other hand, the suspicion that the stigmatized is a con man (or con woman for that matter) denies a certain individual the right to claim divine affliction. Both rationalizations say nothing more than that there are individuals who either are under the spell of illusion or are trying to fool the others. In a more 'systematic' mood, these explanations can be taken as techniques of how not to suspend our disbelief in the likelihood of the divinely inflicted wounds. This would lead inductively to the general statement "there are no stigmata." But what counts is the symbolic value of the wounds, for the stigmatized body is Christ-like. Unlike the umbilical "scar," marking our lost communion with another body, the five stigmata of Francis celebrate the divine embrace and mark the promise of salvation. Francis is a man of God: he bears the divine trademark.

At the other end of our story, which happens to take place on the night of November 23rd to 24th, 1654, in Paris, Blaise Pascal had an ecstatic experience. Following his nuit de feu, he finally committed himself to fight for the Christian faith as it was understood by bishop Jansenius' followers. Relatively shortly thereafter (January 23, 1656), this "ami dévoué et sûr de Port Royal" was to publish (although the author's name was not publicized then) the first of his Lettres Provinciales in which the attack on the moral laxity preached by the Jesuits is typically Jansenist. 
Pascal never spoke about his experience, and, if it were not for a piece of paper found, a few days after his death, sewn in the lining of his coat, the world would not have had any notice of what happened that night. When, eighty years later, in 1742, this piece was first published, it has been given the title Le Mémorial.

Although the text is a most revealing proof of Pascal's conversion, one should not infer -- though it has been often inferred -- that the Mémorial represents a final reconciliation of the opposite sides of his thought. Nor should one decide hastily that the Mémorial has left a clear imprint on his subsequent writings; the Pensées and the Provinciales have, stylistically speaking, little in common with it. Both Pascal's faith and his style require that his search go on. Pascal's God, who is neither found nor lost but always present, utters Tu ne me chercherais si tu ne m'avait trouvé... To the anguished soul this presence is revealed as Lord's suffering exacting a similarly painful imitatio: Jésus sera en agonie jusqu'à la fin du monde: il ne faut pas dormir pendant ce temps là. The Mémorial appears to be a moment of radical sleeplessness, so unique that the tragic thought of Pascal is, for once, overcome.

To many, this seemed to be the most un-Pascalian of his writings, an apparently ruleless combination of French sentences lacking verbs, Latin inserts, abundant in unwritten exclamation marks, breaking the bonds of syntax; in all, an unstructured chain of

words praising God and exhibiting both the frenzied happiness of an accomplished union with the absolute and the despair of being separated from God:

1 L'an de grace 1654

2 Lundy 23 novembre, jour de St. Clément, pape et martir

3 et autre au martirologe veille de St. Chrysogone martir,

4 et autres. Depuis environ dix heures et demy du soir

5 jusques environ minuit et demy.

6 FEU

7 DIEU d'Abraham, DIEU d'Isaac, DIEU de Jacob

8 Non de philosophes et de sçavants

9 Certitude, certitude sentiment Joye Paix.

10 DIEU de Jésus Christ

11 Deum meum et Deum vestrum 


\section{Ton DIEU sera mon Dieu}

13 Oubly du monde et de tout, hormis DIEU.

14 Il ne se trouve que par les voyes enseignées dans l'Evangile.

15 Grandeur de l'ame humaine

16 Père juste, le monde ne t'a point connu, mais je t'ay connu

17 Joye, joye, joye, pleurs de joye

18 Je m'en suis separé

19 Derelinquerunt me fontem acquae vivae

20 Mon Dieu, me quitterez-vous?

21 Que je n'en sois separé étérnellement

22 Je m'en suis separé, je l'ay fui renoncé crucifié

23 Que je n'en sois jamais separé

24 Il ne se conserve que par les voyes enseignées dans l'Evangile

25 Renonciation totale et douce

26 Soumission totale a Jesus Christ et mon directeur

27 Étérnellement en joye pour un jour d'exercice sur la terre.

28 Amen.

The scene stands under the sign of fire, the text itself burns unconsumed by its flames. Everything seems too visible in this confession that says what it shows; yet, most critics have been blinded and have produced a respectable amount of direct

approaches to the Mémorial, that certainly do not contend for the title of the most interesting collection of criticism. A central equivalence was discovered which, later, could not be abandoned by critics. The equivalence is offered in a simple way by the author himself: Feu and Dieu are the only words written in upper case letters. But no one paid attention to the fact that the two words rhyme, inviting one to listen for the text. The blatant visuality of Feu is doubled by -- as it darkens -- the audibility of fire. The sound of the word 'fire' triggers a process imperceptible to the eye. The sounds stand in the shadow of fire, but listening to them may be fascinating, for they tell a story not of the experience, but of the text, of a different experience. 
The exclusively visual grip on the text has been reinforced not only by its visionary character, but also by the contexts in which it has been written, found, and read. Any time one reads it -- aware of the secrecy of the Mémorial--, one probably feels as if one is peeping through the keyhole at a scene not meant for "representation." This exercise in a small yet comforting obscenity leaves the unaware actor unprotected against the eye of the unwelcome spectator. The mystic turns out to be ridiculous, superstitious, evil, insane. How could one explain otherwise the absence of Pascal's wonderful prose? The author seems to have been forsaken by the génie de la langue française. He speaks in tongues -- the combination of French and Latin is effected under the sign of the Pentecost. He forgets grammar, yet the Mémorial is not a-grammatical: the lack of verbs (ll. 1-11, 25-28), the "unhappy" ambiguity of the deictics, and the ruptures harrassing the syntax point to the anagrammatical shaping of the text. The ear, however, can recover the rhythms beating here:

Renonciation totale et douce

Soumission totale a Jesus Christ

et mon directeur

Étérnellement en joye

pour un jour sur la terre.

d'exercice

Amen.

The last lines of the Mémorial reveal prosodic elements pertaining to two different -- or rather incompatible -- orders. The first two lines are submissively melodious as if the text had arrived at the final peace in a Bernardian Christical embrace. But as in Teresa de Avila's spiritual testimony the embrace is not projected onto the screen of eternity and left there to reign over the historical future of both author and reader. Unlike Teresa, Pascal's ecstatic confession does not set the embrace against the more painful experience of the Virgin; here it is the disrupting intervention of God the Father (mon directeur) that pulls the text from embrace. Now the rhythm changes, étérnellement en joye, although, under the influence of the previous lines, we hear its feminine rhymes (jour and terre are read as each having two syllables). But the new rhythm is broken by exercice, a word that echoes its anapaestic predecessor directeur. In more than one sense, exercice lies at the center of the line: prosodically, it represents the caesura between two identical hemistiches. But as exercice breaks the (effeminate) harmony, it opens a different prosodic order in which it surrounds itself with a pair of peers, two anapaestic sequences: pour/un/jour and sur/la/terre. The directed action (exercice) finds a place for itself in the new rhythmic order which it itself triggers. 
Moreover, the harmonic tension of this semantic prosody is heightened by the etymological play in which the word exercice recalls its Latin predecessors, exercitium and exercitus (army). The drums of the new rhythm recall the drums of the army which does not actually fight but only prepares itself (exercitium) for future battles. Pascal's exercice announces his being a miles Christi who promises to fight for true faith. The exercice exceeds itself as it crosses several boundaries of language, and, as it did create a new rhythm and placed itself at its center, this so active word opens now a wide "magnetic" field of alliterations. (It is unrewarding to attempt to discriminate between "intended" and "unconscious" meanings in the Mémorial. The text is so rich that it dismisses the stable position of the "reasonable author," and invites the reader to turn around and enter the dance of its tourbillon. Pascal's own play invites critical

playfulness to participate in the joy of this text. One can accompany the Pascalian exercice only with one's own anagrammatical introvertige.) The exercice follows a pair of alliterative words (joye / jour) and emerges as their verbum: jouir. The desire not to be separated sweeps across the text and leaves its mark imprinted on the words; exercice calls, as it invents, its peers. As jouir, it points back to je l'ay fui, the statement of Pascal's guilt; once the guilt is acknowledged, the repentance of the enlightened Christian acts as a somersault which projects him into the space of jouissance. But as the alliterative structure shows, repentance is not the primum movens of the process leading to jouissance: it is only the middle of the story that effectively starts with FEU. The vision of fire stimulates an overwhelming 'certitude' which bids the slightly altered alliteration 'sentiment' as a mediation between itself and the crystalline Joye Paix. But the self acquires the certitude that it has found the joyous way to God too soon (as if he were implying that "parmi les voies enseignées dans l'Évangile, j'ai pris la voie de la joie"). Too certain, the self utters a half impiety (Grandeur de l'âme humaine), and immediately identifies itself from the perspective of Christ (Père juste, le monde ne t'a point connu, mais je t'ay connu) -- impiety in full. One can overhear the duplication of the juste: "Père juste (...) juste moi" as the mark that the proud self-assertion has already been committed. It comes as a shocking surprise that the tears of joy reflect not only their divine cause, but also the punishment for the sin committed: from beyond the abyss of separation, they are "dried" by the feared loss of "the fountain of living waters." (pleurs delays the alarming approaching of the crevasse of separation; it suggests an extra-individual weeping (pleurs (...) il pleut) as it avoids the sensitive larmes (...) alarmées.) The self did not obtain the vision of fire in order to become Godlike: the first impulse was to identify itself with Christ, as the first time when je occurs in the text is in the Christic je t'ay connu. The self was quite willing to place itself in the high trinity of feu, $\mathrm{Dieu}, \mathrm{je}$. Now that this identification has been gratified with what the mystic fears most -- separation, the self recedes from its Christic posture, to an uncertain stage: "Will you forsake me?" And it recedes further, pushed by every new line, as if it were superstitiously careful not to 
advance any daring (sup)position, repeating the wish in a most perfect form. Que je n'en sois pas separé éternellement is an expression that "misses" the target, as its ambiguity allows for momentary separation. In order to find the right expression of the will, the self has to dissociate itself from Christ, to use the style indirect libre as the right way of confessing its guilt: "[Je vous confesse que] je l'ay fui (...)" Only now is the self free to express itself properly, to become a je who demandingly begs: Que je n'en sois jamais separé.

The whole alliterative trajectory now comprises the dejected "feu -- Dieu -je" as it overcomes it in the encompassing triad "feu -- fuir -- jouir." In the very experience of writing, the je cannot approach Dieu directly without being sinful. The I sees the fire but it is only through the mediation of the tears that reflect everything, good and bad, past and future, that this I can represent its mistaken vision. For the vision cannot be taken at the face value; it undergoes a process of dramatic interpretation within which the mind gets transformed: here, repentance really means "the change of mind," metanoia. Pascal's self is now at the disposition of his God "jouirisdiction," ready to "dance and fight," as it comes to the terrestrial punctus terminus of the text: (...) terre amen.

The text grows in dramatism as it progresses. It is not a mixture of "pure" experience" and "interpretation," but it establishes itself as a narrative despite the ruptures and the collage of Biblical quotations. The care with which Pascal notes the time at which the experience took place (the first five lines) announces the importance of what follows: this is something to be kept. The word feu may refer to the actual experience but it certainly looks forward toward the text it triggers. The pen discharges, takes fire, but not suddenly. It throws in scene the "true God" of the patriarchs, yet it is still the stylus of a "philosopher" as long as it has to distinguish between the true God and the God des philosophes et de sçavants, and to present the forgetting of the world and everything hormis Dieu. The tears temper the spirit of the philosopher who, changing his mind, becomes the Christian dialectician. For, it could be said now, the

Mémorial is in line with Pascal's Christian dialectics, is, as it were, its experiential proof: the fallen state of the human soul cannot be understood without the assertion of its grandeur, and the joy of an eternal future has no sense if it has not been experienced as the monstrous indifference of the humus, as human humility: S'il se vante, je l'abaisse, s'il s'abaisse, je le vante, et le contredit toujours, jusqu'à ce qu'il comprenne qu'il est un monstre incompréhensible.) In his confession Pascal does not acknowledge the dull directedness of "pure experience": "il ne fait pas l'ange." It is rather the process of writing up this experience that introduces it in the Pascalian canon (as it fires). Writing heightens experience from truth to verisimilitude. Yet, who writes this text? This is a question that Pascal's own alliterations seem to address in the sequence: directeur -- terre -- amen. One may suggest that the text itself is not only inspired by the transcendent, but dictated from above. As the day of 'exercice' on earth is substracted from eternity, the terre pays its prosodical -- and ontological -- debt to the 
directeur -- and what remains, cleaned of earthly remains, is une écriture céleste, a dictamen. The ambiguity of directeur is now solved, but not reduced: the directeur is neither God the Father nor Jesus (Christ et directeur) but the author of the dictamen (le directeur de plume), and by this fact, both God and Jesus, di-recteur. Pascal will dwell on the paradoxical field open between the two, in the unceasing Ghostly tension of their different rhythms and divine deferrals. The sense of fully belonging to the divine is not devoid of dynamism. Like Augustine and Teresa, Pascal brings to light the active paradoxality of life after the mystical experience is consummed: Adhaerens deo unus spiritus est; on s'aime parce qu'on est membre de J.-C.; on aime J.-C. parce qu'il est le corps dont on est membre. Tout est un. L'un est en l'autre comme les trois personnes (Pensées, [[section]] 372 (Brunschvicg, 483)). In this prefiguration of Derrida's différance one could read the only acceptable way for for the ego's being. Otherwise, for Pascal le moi haïssable, and from this exacting morality one could expect nothing more than a reactionary and unbearable imposition: Expect no mercy or indulgence from Pascal. He is infinitely cruel with himself and infinitely cruel with others. Je n'approuve que ceux qui cherchent en gémissant. He kills every

kind of consolation. He discards all that is dear to man: he promisses weariness without end, changes earthly life into terrible chaos (Shestov, 1975:287).

The initial "superstition" that leads Pascal to note the date so carefully -- do we not suspect that "the clock of the martyrs," the martirs-horloge, alludes three fateful times to Pascal's fear of not lying (martir -- mentir) -- is eventually discharged as he sees the promise of eternity. In the heavenly dictamen, the new age is shaped: never in the history of Christianity has the word amen been more motivated than it is here. Pascal knew how to end a story that extended far beyond himself. He kept the Mémorial at his chest, a precious but secret stigmatum, and also a reverse purloined letter posted to his future selves, not to be stolen by the thieves of time. He knew his text by heart.

In their ascetical practice both Francis and Pascal punished the natural impulses that deliver the body to history. Pascal seems to announce the "dark night of the body" which was about to begin in the West with the first signs of the luminous "age of Reason". It is not surprising that once the historical consciousness begins to influence "history", the body is withdrawn from history. Pascal is only one of the last "reactionary" mystics of the 16th and 17th century who indirectly prepare the "coming of history" by withdrawing the body from the world, and leaving the world to historicize the body politic and the corpus mysticum of the Church. In painting as in the punitive actions of the State, the body becomes more and more an abstract entity which, either unmentioned or "privatized" (unmentionable) escapes the centralizing practices of 'history' and 'progress'.

Yet the ascetical building of a mortified natural body is only the first step toward acquiring a new body in a different temporality. Pascal's Mémorial 
acts as a cardiac stimulator that teaches the heart how to beat in the new age. The new temporality emerges within his experience: the epoch that starts with an event so powerful that it makes one tremble. This fire is not the final one, the ekpirosis in

which expires the mandate of this world. The epoch (aevum, aeon) denotes a third temporality, whose meaning is so uncommon that it has to be carefully situated. On the one hand, there exists the temporal order called aidiótes by the Greek Fathers, corresponding to the totum simul of aeternitas.

Augustine called it, "a now ever standing" (nunc semper stans), or, as Dante put it, il punto/ a cui tutti li tempi son presenti. This is the "timeless temporality" of God who, having no origin and end, is alone eternal in the true sense.

On the other end there exists the tempus (chrónos) proper to the creature, the "present age," that, by nature, tends towards non-being, and from whose bondage the human being can be rescued by "the awesome power of memory":

If the present were always present, and would not pass into the past, it would no longer be time, but eternity. Therefore, if the present, so as to be time, must be so constituted that it passes into the past, how can we say that it is, since the cause of its being is the fact that it will cease to be? Does it not follow that we can truly say that it is time, only because it tends towards non-being? (Augustine, Confessions, x.14)

Between the two is inserted the epoch, which, according to Maximus the Confessor, is known to angels and to those human persons who possess the "knowledge of the age to come." The epoch, one can contend, is the temporal order of mystical experience. The concept of epoch was not used in the Middle Ages (or so the Scholastics maintained) in order to revise Augustine's dualism of tempus and aeternitas, and to open up the problematic of an unlimited continuity which was neither one nor the other. My contention is that Augustine was perfectly aware of the necessity of introducing a third temporality, even if he did not use the term aevum. As it happened with another medieval "intermediary," the purgatory, the idea has been there for a long time, yet it has been sharply conceptualized in the West only after the twelfth century.

For Augustine, the concept of coeternal creature is

impossible. Before the Creation there was no time, yet not everything that is created is refused access to eternity. Augustine introduces a mediating term between time and eternity. Following the argument of Plato, he suggests the existence of what can be called the infinitum post hoc:

What Plato himself expressly stated is that the world and those gods whom God put in the world began to be and had a beginning, although they will 
have no end, since the will of the all-powerful Creator will keep them in existence forever. However, the Platonists have invented a way of interpreting this, saying that beginning means causal subordination, not an order in time. They say: 'If from all eternity a foot were standing in dust, there would always be a footprint beneath it. No one would doubt that this footprint was caused by the pressure of the foot, but no one would think that the impression came after the foot, even though it was caused by the foot. In the same way, the world and the gods created in it have always existed, just as their Maker has always existed; yet they were made.' (...) take the happiness of the soul. After the experience of evil, it will be secure for all eternity. As Porphyry himself confesses, happiness undoubtedly begins in time, although it is to continue forever, in spite of having no previous existence (...) Thus, that whole argument falls to the ground which supposes that nothing can be without an end in time unless it was without a beginning in time. It was enough to show that the happiness of the soul, which had a beginning in time, will have no end in time (De civ.Dei, x.31).

Augustine's rejection of the "Platonists" is indirect and seemingly weaker than expected. The argument itself is a sophistry: a difference (foot/ footprint) can exist but in time, either because the foot has to be lifted in order for someone's eye to see the print, or because, the foot standing in dust, one has to infer the presence of the print beneath it. As it is given, the argument is a petitio principii whose conclusion -- "there are things which are caused but not

preceded by their cause" -- is already given in the premise. It has been argued that logic was not his strength, but here he does not commit any "mistake," rather he abstains from tackling directly the logic of the argument. Had he demonstrated its falsehood, he would have arrived at an untenable conclusion: if causality and temporality were interdependent, his whole theory of Creation would have been undermined and God himself thrown in time.

It is inappropriate to think of Augustine as a mystic, but his influence on the seventeenth-century Jansenism could hardly be overstated. His infinitum post hoc stands in the background of Pascal's epoch.

In the Mémorial we witness an experience of such an epoch-formation: the temporality of the creature which, bowing down before its directeur, becomes fully aware of its own creatureliness, and realizes the eternity before it. The process is triggered by a vision the power of which cancels out the historical time: the first moment of the epoch-formation is an epochalypse.

The fire that starts this new "age", the epoch of Pascal's devotion is, no less, a command: discharge! His epochal experience seems to effect the transition from the Biblical canon to the anti-Jesuit cannonade. However, this is too settling an interpretation of a text that merely puts the subject at the service of a new devotion. In the rhizomical sensitivity of the Mémorial, 
the ascetical body of Pascal is elevated to the status of a new body, ready for martyrium.

There is a crucial tension in Pascal's text, indeed in his oeuvre, between the mortification of his body and what can be done with that body afterwards. Among the ways to appease the tension and "make a claim" for Pascal's ideology, there are two which interest us here, for they represent the limits of the appropriation of Pascal's thinking. The theologian will appeal to the settling Ereignis, and claim that Pascal was getting ready for martyrdom, that his refusal of mundane pleasures was nothing other than an offering for eternity. The liberal thinker, on the other hand, will take for granted

the theological reading and, as Aldous Huxley did outspokenly, will chastize Pascal. Not because the Catholic is a species of heautontimoroumenos (Pascal did not love life, all right, this was his problem) but because, as a moralist, he preached self-mortification. He ought to have spoken for himself, triumphs the liberal whose gentlemanliness would have been delighted to deserve at least one Provinciale. Huxley addresses his antiPascalian attack to a well-behaved and a bit innocent audience, which, he fears, may be tempted into self-mortification. And, although his pro domo is not particularly brilliant, it is paradigmatic for a superficial laissez-faire attitude that formally resembles the mystical Gelassenheit, while substantially clashing with it. Huxley lacks candour when he counteracts the ought of the moralist with his counter-ought. One needs to look at Huxley's presuppositions in order to understand that, once more, something which is done "for life's sake," disguises, in fact, a subliminally powerful ideology. Huxley filters his 'enlightenment'thinking through the opposition between Blake and Pascal, whereby the life-worshiper triumphs over the other, who is sick unto death. The typicality of Huxley lies in the fact that he is a "modern" assured of the justness of his claims against the other sort of mortification, present in the history of positivist thinking, in the dull theory of social progress, and the overall mechanization of the social. His plea for life stems from the commonsensical idea that reality as we know it, is an organic whole (230). As a learned Englishman, Huxley thought that "organicity," when presented in a commonsensical fashion, explained everything to everybody. Yet, if somebody wants to get access to everything by means of common sense, one should gaze at what Huxley's social landscape looks like:

The great Leviathan of mediocre humanity presents its vast, its almost immovably ponderous bottom; there is a dull and suety thudding; the boot rebounds. Sometimes, when the kicks have been more than usually violent and well directed, the monster stirs a little. These are the changes which it has been fashionable, for the last hundred years or so, to describe as progress (280-81).

Huxley's Anglican double standard goes awry as the author is forced to suggest, against Pascal's unbalanced excess, the idea that, as the world has been moved (...) only by those who have lived excessively (280), one should be excessive in a liberal way. This aesthetic liberalism fits Huxley's work in general; for him, the subject is a set of possibilities and it becomes "unreal" 
if it does not realize as many of them as possible. The Huxleyan excess, which is rather quantitative and rhetorical, has few things to share with experienced excess. His philosophia perennis that helps him misunderstand the Mémorial, obtains at a then cheap price: Huxley used drugs as a password, a shibboleth for the world of "the highest eternal truths," and did not care for the suffering implied in the ascetic cognizance. The liberal laissez-faire is eventually supported by a walk to the drugstore, rather than by the work of the will.

Returning to Pascal's accomplished askesis, one may find another way of interpreting it. Perhaps he does not offer his body exclusively to martyrological actions. Perhaps both the Catholic theologian and Huxley reduced the value of a gesture that is intrinsically richer. The reading of Pascal is an exercice in complication --and for Nietzsche the desire to annihilate Christianity overpowered his temptation to complicate himself. Sartre, in one of his bon mots, said that it is not important what history does to us, but rather what we do with that which history has done to us. Pascal's askesis appears to be a legitimate way of doing away with history by -- never completely -- withdrawing the body from beneath the conditions of the temporal. Yet, what he does with himself after this withdrawing, is a matter not of history or eternity, but of epochality.

To become an epochal and acquire an epochal body, one needs to construct oneself as such, to plunge through time and eternity. It is to offer oneself to the eternal agent, yet to be able to keep the contradiction alive and sense this agent in its prohibiting paradoxicality. Pascal is not a thinker of pure désoeuvrement, although the works he brings to an end are ever open to self-denial.

One may claim that the Pensées are not as much the project of an unfinished opus on Christianity, but that they are simply Pascalian. His dialectics never ends.

Pascal's ascetic project was to dis-organize his own body and, in so doing, prepare it for the epochality attained in the nuit de feu of November 1654. In this, the "sublime misanthrope" is definitely a mystical thinker, at odds with the belief in organicity. At odds, therefore, with the chlorophyllic Romantics and the chlorotic Romantics, with Darwin and Marx, with all the glorious thinkers of the function, the lawful guardians of the inherited ideas of the Renaissance. For Pascal, the ideal state of things would be that in which any-body becomes a part of the Christian body (Pensées, [[section]] 373), the individual being transformed into such a member by the power of grace, into a part of the corpus mysticum. To this project sponsored by his morality, Pascal's Mémorial stands as both illustration and overcoming. On the one side, his body is a functional part of the corpus mysticum. On the other, given the lived paradoxality of his God, this belonging can never be effected, as faith without reason is an excess. Reason prevents the body from being plunged into the great divine aggregate. Pascal's reason is still the factor which discriminates between body and soul. He is not an 
optimystic, but a thinker torn apart by the interventions of reason. The epochal body cannot be an organism, but a wound that, in its vibration, echoes the stigmatizing moment of its constitution. The Mémorial is secret as it is such a pumping wound; in public, it would cease to beat; looked at, it turns into a scar on the map of events, and into a symptom of whatever the intelligent reader wants to prove with it. One has to look sideways at this body / text in order to miss it and recuperate its image indirectly, as one does not see a star if one looks directly at it, but only if one targets its surroundings. Reading this text, we feel at fault, regardless of the pleasure we might derive thereby. The moral of the story is that a direct apprehension of an epochal body is impossible. One cannot con-front this body because it does not exist in the way material bodies do exist, and also because it does not have a conceptual shape. Yet this does not mean that it lacks materiality. The epochal

body is an entity that has overcome the split between body and soul (or spirit, mind, reason, etc.) It is not disorganized, although dis-organization leads to its formation. As the notion of the epochal body is crucial to the existence and understanding of mystical testimoniality and its relation to history, I will devote a few pages to this rather uncommon entity. Two issues are of interest in the discussion of the epochal body: how does something which feels persevere even after the death of the body? and what is the relation between this something and the ensemble of historical somethingness? The first question bears upon the age-old obsession with immortality, whereas the second is involved, more precisely, in the medieval transformation of the notion of corpus mysticum. We should not withhold our desire to establish the conditions under which these two questions, once situated with reference to the corpus epochalis, may address the issue of a contemporary re-organization of knowledge. In our terms, the problem may be stated as follows: under what conditions can the notion of epochal body come alive, what re-organizaton of knowledge is necessary to make such a move credible?

The notion of corpus mysticum has a glorious history in the Christian Middle Ages and during the "premodern" centuries (XV-XVII.) It relates to the concept of the Church as corpus Christi, and therefore goes back to St. Paul. Following the Carolingian controversy about the Eucharist carried over many years by Paschasius Radpertus and Ratramnus, corpus mysticum has been used to refer to the consecrated host. Ratramnus pointed out that the body in which Christ had suffered was his "proper and true body" (proprium et verum corpus) whereas the Eucharist was his corpus mysticum. Until midtwelfth century, the Church (or Christian society) continued to be known as corpus Christi in agreement with the terminology of St. Paul. In the dispute over the doctrine of transsubstantiation in the eleventh century, against Berengar de Tours and the teaching of heretical sectarians, who tended to spiritualize and mystify the Sacrament of the Altar, the Church was compelled to stress more emphatically, not a spiritual or mystical, but the real presence of both the human and the divine Christ in the 
Eucharist. The consecrated bread was now termed significantly corpus verum or corpus naturale, or simply corpus Christi, the name under which also the feast of Corpus Christi was instituted by the Western Church in 1264. The Pauline term originally designating the Christian Church now began to designate the consecrated host; contrariwise, the notion corpus mysticum, hitherto used to describe the host, was gradually transferred -after 1150 -- to the Church as the organized body of Christian society united in the Sacrament of the Altar. In short, the expression "mystical body," which originally had a liturgical meaning, took on a connotation of sociological content.

The doctrine of transsubstantiation -- culminating in the dogma of 1215 (Latran IV), by which the Eucharist was officially designated as corpus verum -- was a part of the development of the term corpus mysticum as a designation of the Church in its institutional and ecclesiological aspects. This placed the Church as a body politic, or as a political and legal organism, on a level with the secular bodies politic which were then to assert themselves as self-sufficient entities. The institutional side of the church becomes "mystical," whereas the communion with Christ in the sacrament of the Eucharist becomes "real":

The terminological change by which the consecrated host became the corpus naturale and the social body of the Church became the corpus mysticum, coincided with that moment in the history of Western though when the doctrines of corporational and organic structure of society began to pervade anew the political theories of the West(...) It was in that period that (...) John of Salisbury wrote those famous chapters of his Policraticus in which he compared, under the guise of Plutarch, the commonweal with the organism of the human body, a simile popular also among the jurists(...) [while] in Isaac of Stella's sermons, the anthropomorphic imagery was transferred as a matter of course to both the Church as the "mystical body of Christ" in spiritual sense and the Church as an administrative organism styled likewise

corpus mysticum. [Isaac] compared Christ with a root of a tree, this mystic body whose head is Christ and whose limbs are the archbishops, bishops and other functionaries of the Church, is "semblable à un arbre renversé (Kantorowicz, 1957:199).

Now the notion of corpus mysticum describes the body politic, or corpus iuridicum, of the Church or, by transferrence, any body politic of the secular world. The corpus verum, through the agency of the dogma of transsubstantiation and the institution of the feast of Corpus Christi, developed a life and a mysticism of its own.

Michel de Certeau picked the story of mysticism from where it was left by de Lubac's flawless conclusion: Des trois termes (...) qu'il s'agissait d'organiser 
entre eux (...), corps historique, corps sacramentel et corps ecclésial, jadis la césure était mise entre le premier et le deuxième, tandis qu'elle vint ensuite à être mise entre le deuxième et le troisième (de Lubac: 1949:281). De Certeau mistakenly states that the corpus verum ne qualifie plus l'Église, mais l'Eucharistie, for the term has never signified the Church (designated as corpus Christi before the twelfth century.) The mistake has rather important consequences, as de Certeau sees in this reversal of mysticus (caché) et verus (véritable, réel et connaissable comme tel) (...) un chiasme du signifiant et du signifié (ibid.). This leads him to see in mysticism -- and especially in that of the sixteenth and seventeenth century, the desire of the dispossessed to have a body. The corpus mysticum appears then to be 'the absent body'; le discours [eucharistique], hoc est corpus meum, rappelle un disparu et annonce une effetivité. Ceux qui prennent au sérieux ce discours sont ceux qui éprouvent la douleur d'une absence de corps (de Certeau, 1982:108). What comes to fill this absence of the body is de Certeau's own structural schemes and formulae, as if they were running in parallel with the desire of the mystics. The fact is that such a reading of the history of mysticism leads to the unsettling conclusion that the mystics lack a body. On the contrary, it seems to us that the writings of St. Teresa, Jeanne de la Motte Guyon, Richard Crashaw, Pascal and the others, display

the worry that the mystics might have too much of a body. Their problem is not how to acquire a body in order to fill an absence, but how to trade their mortal body for an epochal one, how to empty (entleeren) it, how to discharge it. From this perspective, one can see that the invention of the corpus verum -- and not its displacement -- has been, at least from the thirteenth century on, the expression of a reaction against the institutional alliance between the church and the secular corporations. The mystics had been pushed aside from the play of power and law and had to find a reality (veritas) outside that realm of absence that was the social. The thirteenth century has been not only the century of the jurists and scholastics, but also of powerful religious revivals, of Francis and Dominic, of the Beguines, etc. When, by the end of that century, the "massive" religious enthusiasm had considerably faded, it was the turn of the (Northern) mystics to challenge the holy alliance between secular power and the Church.

The trial of Eckhart, in 1327, represents only the most exemplary clash between the already frozen, corporatist corpus mysticum and the lively, "heretical" corpus verum. The issue remains more or less the same at the end of the seventeenth century, when Miguel de Molinos was tried and, with the generous help provided by the Company of Jesus, found guilty of heresy.

From a certain perspective that comforts the lazy historian but brings the alert student of the past on the brink of despair, it was "natural" for such clashes to exist between the apparatus of ecclesiastical power and some authors who made it too clear that they were feeling the presence of God outside and beyond any institutional frame. This was inscribed in the "essence" of Christianity, predicated upon the paradox of the incarnated Verbum, and as such, it remained unchanged. But from a perspective that takes into account the historical context, it makes a difference that Luther 
succeeded there where Hus did not, and that the same Luther eventually won the trial, whereas Eckhart and Molinos had to concede defeat. The question remains whether there exists the possibility for a double perspective, which would take into account

these issues: (1) Christianity is a religion erected on a paradox that remained unchanged throughout its history, and (2) the diversified landscape of historical events is to be explained without eliminating the paradox. Kolakowski has tried to settle the problem in eight hundred pages and the result is not convincing. In fact, all historical approaches to mysticism have to deal with the minimal historicity of their object, and historical conclusions can be all but -- with a risky expression -- conventional acknowledgments of the almost complete internal irrelevance of history for mysticism. While mysticism is relevant for history at the level of events (Eckhart's trial, San Juan's imprisonment) and of general developments (the Cathars' heresy, the mass hysteria in 1930s Germany), the reflection of history in mysticism seems, at most, marginal. In this sense, one can talk about history but not about mysticism, and the history of mysticism is the story of its falsifications. The mystic appears as s/he leaves the historical world; her/his story is woven around Weltlossigkeit. It is an instantaneous appearance, as the mystic vanishes immediately: we see her/him in a fulguration, on the border of the world (there where dwells the Wittgensteinian subject). The non-falsificatory history of mysticism could be but embodied scarcity, while a more "substantial" history need to trade mysticism for its irrelevant aspects in order to make its own discourse possible.

But one may hope to find a way of discoursing historically on mysticism. In order to do so, the very concept of history has to be reworked under the horizon of mysticism. This was one of the aims of de Certeau, and if he failed, he did it in an exemplary manner. His Fable mystique explains why this happened. As long as de Certeau dealt with the critique of the pervading Hegelian model of history, with the implementation of alternative histories developing independently one from another, with heterologies that claim their right to live against the all encompassing "belly turned mind" of the system, with the humane attitude of giving the other its due right, all seemed to work well within his framework. But when it came to follow his own suggestions in the field of the "positive," that is, to account for history according to his own terms, he found

himself in the same position as Foucault did when he had to advance a blueprint for social action based on his critique of the mechanisms of power and repression. One finds as little history of mysticism in de Certeau as one finds program for action in Foucault. These absences are understandable in two ways: first, because of the desire to avoid the Hegelian excess. De Certeau abstained from mystifying history (an upright antihegelian reaction), warned, as he was, by Foucault's eventual surrendering to the analytic methods he himself had unearthed and chastized. Foucault was a political thinker defeated by his own political (analytic) action, but at the same time, he had the right taste (happily, he was under the spell of 
Nietzsche and not of Marx) not to present a program of action. Michel de Certeau realized that he did not have the vigour of the prophet to renounce delicacy and present a history of mysticism. Although the protest against historia is already present in his choice of the fabula, there are many moments in his approach where de Certeau gives way to the historian, and those are not the most felicitous. The second reason for the aforementioned absences in de Certeau and Foucault has to do with their understanding of one of the basic issues in Hegel's treatment of history. There is a relationship of mutual election between reason and history in Hegel that makes his explanation so powerful, although it leads it eventually to arrest history in a mystical nunc stans. One can appreciate that this is the most "Jewish" aspect of Hegel's philosophy: reason elects history as the medium of its unfolding, while history elects reason as the light of its own understanding and subsistence, very much like Jahweh elects the people of Israel and is elected by it. The wanderings of the people of Israel find their parallel in the modern homelessness on which Hegel's philosophy of history is eventually predicated. The mutual election mutes the voice of the mystical presence, as it is essentially prophetic in nature. Hegel's philosophy of history is situated in the vantage point of this presence, the historian empowers his voice with its attributes in order to have claims over the future. Where the mystic embraces the presence for its own sake and is returned to the earth in order to tell the story, the prophet "speaks the voice of God," is God on earth indeed. Where the mystic is always too late, the prophet is too early. The former

lives in urgency, the latter imposes an emergency upon the others. No wonder that the prophet and the philosopher of history see death down on earth and ahead in time, whereas the mystic sees life before and above. For both, there is nothing to be done and everything to be willed.

As long as it is at odds with this fundamental mutual election (God and people, reason and history), mysticism cannot have a history. This was understood by Michel de Certeau, and his legacy prompts us to follow, as far as we are able, the non-mutuality, the great dissymmetry on which the mystical mode is predicated. For, the mystic has a patria: s/he has been there. The mystic is elected but $\mathrm{s} /$ he does not elect. The mystical, ecstatic embrace is not identity as it is not the symmetrical gesture of two bodies: there is always a distinction between the lover and the beloved, a difference in presence. To this, one opposes the indifference before the Law, that is the similarity imposed by absence. Without the former, mysticism cannot exist, whereas history has no possibility of being without the latter. This shows why history and utopia make such a good pair of opposites: they belong to the same "Law-type." Although apparently similar, mysticism and utopia are most remote from one another. For the mystic nothing is as disgusting as utopia, not even history. The mystical reality of non-substitution is functionalized by utopianism to the margin of death. The eighteenth century has both abandoned mysticism and decidedly settled for utopia as a means of counteracting, at least symbolically, the alienating advance of the history of reason, thereby attempting to arrest the unforeseeable and cruel games 
of the mutual election. The utmost result was to be witnessed by the twentieth century under the form of the mutual molding of history and utopia. If one thinks today of mysticism in a thorough way, it is primarily because of the deadly results of this totalitarian blurring of differences between history and utopia, a utopia which is itself negative with respect not primarily to its eutopian predecessors (More, Campanella, etc.), or to history, but to something for which we do not even have a name. History has come not to an end, but to the point where it is no longer able to engender utopias. Now, another opponent has to be sought in order for history to be understood.

Under these conditions we think our improbable mystical "tradition" and return to the epochal body as an entity promising not so much a leave-taking from history, as a return to its enlarged concept. Such a concept should be able to dispense with events. Yet this tendency toward non-eventfulness is understood in an extra-utopian sense: it is not final, there exists a necessary moment of return to the world of events, even if this return is not eternal. In the midst of events, suddenly something happens to an entity (individual, community), and this entity is taken away from historical time. We call this happening ecstasis: it opens the different temporality of epochality, where the presence is experienced. The sudden impact of the moment of the institution of an epoch, represented as shock, rapture, anaesthesia, fire, or blow, marks that epoch "forever." The cause of this first moment is intrinsically inexplicable, but the written epochal experience attempts to come to terms with its inexplicability by attributing it to a divine intervention. Painful or not, the epochalypse that starts the epoch is perceived as a gift. When the gift is presented as a (philosophical) datum, one witnesses a transformation of the mystical into a certain kind of metaphysics in the discourse of which God is rationalized as the Causa (prima, in Aristotle and Aquinas; efficiens, in Leibniz). This common Christian theory of history situates the infinitely productive causa in the untouchable realm of eternity. In such theories, eternity and history entertain syntactic relationships, and the more the syntax makes sense, the less is the experience of the gift invited to play a part. The voice of eternity will be lent to the prophet to announce the future events. In the transition of causal explanation from eternity to history, the epoch vanishes.

Testamentary literature basically prevents the epoch from imposing its own image. Whereas the epoch is determined by its initial epochalypse, history is presented by testamentary literature and the grand models (Hegel, Marx) as heading towards the apocalypse. There is nothing like a Last Judgment in an epoch, whereas testamentary literature and the grand models bring history to an end in the complete individual indifferentiation before the highest Judge.

Walter Benjamin, who consistently tried to use the notion of "full presence" in order to rework the concept of history, noted that:

History is the subject of a structure whose site is not homogeneous, empty time, but time filled by the presence of the now [Jetztzeit]. Thus, to 
Robespierre ancient Rome was a past charged with the time of the now which he blasted out of the continuum of history. The French revolution viewed itself as Rome reincarnate (...) Where thinking suddenly stops in a configuration pregnant with tensions, it gives that configuration a shock, by which it crystallizes into a monad (...) A historical materialist cannot do without the notion of a present which is not a transition, but in which time stands still and has come to a stop.

Epochality challenges not only the flat homogeneity unmasked by Benjamin, but also the messianism that leads from Marx to Isaac Luria and eventually to the Vetero-Testamentary idea of mutual election. In an epoch there is no hope and no revenge to be projected on the screen of history. The epoch is indifferent to history, as it does not fear the Last Judgment and recuperates everything that is, as presence. Epochality dis-organizes history. The body that endures in epochal time is the confluence of external and internal 'events', a body indistinguishable from the soul and from the environment. One can understand the status of such a body by duplicating, at the level of analysis (not of psychoanalysis), the purgative practice of the mystics. This is to say that our assumptions are to be challenged which regard the body as an organism.

The more primitive notion of 'body' is already explained -- more or less partially -- as it is situated within a network of "organic" entities, structures, sub-systems, systems, and the like. The organism is superimposed on the body as knowledge tends to project itself in its object. As it were, the body remains the same but it is the organism that evolves, according to the progress of science. Yet this is too crude an approximation. For any kind of discourse there exists a pair body / organism. Science deals with the body considered as that materiality which supports and survives different images of the organism (as science is both 'realistic' and 'perfectible.') The body grants the playground of the organism, yet it has meaning only as a retroprojection of the latter. Such organized bodies may be stars, societies, human bodies, and everything that falls under the focus of science. One of the crucial characteristics of modernity lies in the fact that the idea of organicity has pervaded thinking so deeply that one tends to conceive of something non-organic as "dead" or, simply, non-existent. The anorganic matter is "organic" insofar as it is explained within a certain framework, yet it still connotes "death" as a means of differentiating itself from us. The organicity of the anorganic, of theories (Popper), of texts, especially literary, is built on the model of the human organism. In a major shift in the history of Western culture, the "organism" has progressively replaced the old "great chain of Being." The transcendent Being who granted the existence of the "chain" has proven "disfunctional," has become, from a non-understandable entity, an entity that did not help understanding, an "unnecessary hypothesis" in Laplace's terms.

This shift should not be restricted to a relation between, say, old metaphysics and new science (or "criticism," enlightenment, etc.) The organism is the image of accomplished knowledge that has found its proper object, and is able, proud, and happy to abandon itself to it. The organism 
carries with it major scientific certainties and minor disenchantments. In all, the organism represents the hegemonic satisfaction of modernity with itself. The religious dimension of this satisfaction must not be overlooked: the organism is understanding incarnated, and its power over us is ubiquitous. Organisms live, they are life. The organism is a body experimented upon and subsequently experienced as something organic. When the second step of the process prevails over the first and overshadows it, the religious attitude may install itself. The name of this widespread faith of modernity is organimism. As it is fundamentally optimistic (even there where the feeling does not properly exist,) organimism contains enormous reparatory powers. There are no "living wounds" for it, but all wounds -- as signs of insufficiency

- -- were, are, or will be healed. A wound is a problem and the organism has to solve it, to bring it to the stage of a scar, which represents both the convalescence and the victory of the organism. In certain cases, forgetfulness and plastic surgery are used to efface even this trace.

But organimism fails to engulf those things seen only by the unhappy consciousness of modernity, the disasters that arrest comprehension, and everything that is too powerful to be scared into a scar. Auschwitz, the death of the beloved, the Moscow trials are living wounds that dwell at the locus of the mutual accomplishment of history and utopia. As Albert Béguin memorably put it, the deciphering of history is reserved for pained existences. These existences embody the non-organic, they have no scars but are wounds. They are secluded to their painful epochs. It is the painful epochs that makes us sensitive to the existence of the epoch as such. Furthermore, the radicalization of our moral meditation on history helps us understand how the "pained existences" parallel the old mystics' epochs. If the "wounded" return to the historical world, it is only to communicate with it in dying, as did Simone Weil in her sacrifice. To "organicize" these existences would amount to feeding them to that God against whom they have fought. For their sake, dis-organization becomes a moral task.

How does one dis-organize the body?

The question was addressed by Deleuze and Guattari, and its answer contributes to the preliminary understanding of the constitution of the corpus epochalis. In their second volume of Capitalism and Schizophrenia, A Thousand Plateaus, the two French thinkers imagine a sketchy how-to handbook about "how to make yourself a Body without Organs $(B w O)$." The attempt to help the reader help him/herself is done as a follow-up of Deleuze's and Guattari's notion of rhizome, which has to be understood before exposing their $B w O$ theory. Unlike trees or their roots:

The rhizome connects any point to any other point, and its

traits are not necessarily linked to traits of the same nature; it brings into play different regimes of signs, and even nonsign states. [It] is reducible 
neither to the One or to the multiple (...)it has neither beginning nor end, but always a middle (milieu) from which it grows and which it overspills (...) unlike a structure, which is defined by a set of points and positions (...) the rhizome is made only of lines. Unlike the tree, the rhizome is not the object of reproduction (...) it is antigenealogy. It is a short-term memory, or antimemory (...) it is acentered, nonhierarchical, non-signifying without a General (...) defined solely by a circulation of states (1987:21).

Both the rhizome and the $B w O$ derive from Bateson's notion of plateau, $a$ continuous, self-vibrating region of intensities whose development avoids any orientation toward a culmination point or external end. Deleuze and Guattari call a "plateau": any multiplicity connected with other multiplicities by superficial underground stems in such a way as to form or to extend a rhizome (1987:22). A $B w O$ will be, therefore, a zone of equally distributed intensity; it is non-fragmentable (actually, it is the opposite of a splintered body, the $O w B$ ), and it is not regressive (in Freud's sense). The $B w O$ is an egg (...) the intense germen where there are not and cannot be either parents or children (organic representation). Thus, the $B w O$ is never yours or mine. It is always a body. In order to obtain a $B w O$, and thus the totality of all $B w O$ 's, "an abstract machine" is needed, which should be capable of covering and even creating [the $\mathrm{BwO}$ ], by assemblages capable of plunging into desire, or effectively taking charge of desires, or assuring the continuous connections and transversal tie-ins. Otherwise, the $\mathrm{BwO}^{\mathrm{N}} \mathrm{s}$ of the plane will remain separated by genus, marginalized, reduced to means by bordering, while on the "other plane" the emptied or cancerous doubles will triumph.

In his 1947 "To Be Done with the Judgment of God," Artaud was already talking about the "complete uselessness of the organs," by cursing the cancerous body of America, the body of

war and of money. He opposes them to the plane which destratifies the established violent, Fascist bodies. While enjoying Artaud's violence and Deleuze's \& Guattari's playfulness as alternative ways of dismantling the organism, we cannot follow their respective positions. Artaud pays back with violence the violence of the organism, and in this mirrored gesture one has already stepped into the realm of (fast) action. But the dis-organization suggested by Artaud, Deleuze and Guattari does not return us to the epochal body of the mystics who were still a part of the "great chain of Being". The $B w O$ remains in the world, on this side of good and evil.

The epochal body is a body without organs whose completion does not depend on self-directed action (askesis or mas(s)ochism). There is always the sudden impact coming from outside that finishes off the job begun by the subject. On the other hand, Deleuze and Guattari base their $B w O$ "theory" on an exotic distribution of intensities with which the epochal body has little to do. The latter is instituted by a "transcendent" action (of that sort against which Bateson had protested), and it is exceptionally intense. The quietist 
body, that seems to come closest to the D's \& G's $B w O$, is actually closer to a Henry Miller-type of long-lasting "plateau" of maximal intensity than to the lukewarm Balinese charm. In her finest hour, Mme Guyon felt like unrelentingly delivering the children of Christ, thereby failing to qualify for the abstract machine of Deleuze and Guattari. The $B w O$ cannot be confessed but produced in a series of actions that do not deal the fatal blow to the schizoid structure of language from whose bondage it tries to escape. Such a body is a testimony only insofar as it is replaced by the testimony. The $B w O$ partakes of common dialectics, not of the dialectics of presence.

The corpus epochalis is a gift; its being written up in ecstatic confessions is but an exercise in testimony. The confession passes the gift over to the others. While the stigmatics do not need to write but only -- as St. Francis -to take off their clothes so that the marks be visible, the passing over of the gift is accomplished in the

simplest, (truest?) fashion. The stigmatic's body without organs has no other function than that of bearing the wounds, then being the wounds. The body of Pascal is secret, twice secret, as he wears, under his clothes, both the torturing ceinture and the Mémorial, his body-stimulator. The mystic witnesses with his irreplaceable epochal body.

Between the thirteenth and the seventeenth century, the corpus epochalis evolves from simplicity to complication, from openness to hiddenness. The mystic becomes a discreet person (Pascal) or a discreto (Teresa of Avila), and thus s/he has to write. Those who count less as writers and more as minor but fascinating characters (Antoinette Bourignon, Labadie) continue the stigmatics' showing off. But then it was too late: history was on its way toward crystallization and people no longer had the time to pay attention to the epochs embodied near them. The grand and indiscriminatory Judgment had triumphed over singular epochalypses, and Pascal, knowing it, preferred to remain a Saint Francis of secrecy. His memorial exhibits a function that is particular to mystical literature and that is lost in the great design of history and apocalypse. The mystic testifies to a truth that cannot be implemented in history as such, but history has to be transformed in order for this truth to be apprehended. The transition from the dialectics of presence to the one of absence cannot be effected without loss: the present judgment does not correspond analogically to the last. Testamentary literature displaces the judgment at the end of time; therefore, it does not root itself in the implacable presence, but rather in the apocalyptic emrgency so well suited to bridge the gap between faith and churchly bureaucracy. The ontological span from between the mystical presence and the present moment is changed into the historicized and moralizing distance between the present and the last judgment. In the grand design of Christian (and Hegelian) history, the law replaces love, and the historical body replaces an "eviternal," epochal body whose testimony is lost as testimony and is transformed into an exemplum whereby the constitutive paradoxality of Christianism is deferred. The testamentary infinity is a tautology: it is the infinite deferral of the Last Judgment, the grand blackmail. 
But it is a "living tautology," a cunning of Reason: nobody can perceive it properly because everybody and everything is contained in its belly, and faith is not powerful enough to help the believer ("bellyver") get out. For he who is aware of this predicament, apocalyptic urgency becomes a form of collaborationism with all muddy powers that take over the work of the Creation and dream of bringing it to its happy end. But he who, like Artaud, cries to be done with the Judgment of God, knows that this is not his last word.

\section{University of Toronto}

Centre for Comparative Literature

Toronto - ONT M5S 1A1 - Canada

Surface Page d'Acceuil/Home Page

\section{BIBLIOGRAPHY}

Adorno, Theodor. Negative Dialectics. (1966) Trans. E.B. Ashton. New York: Continuum, 1973.

Artaud, Antonin. Selected Writings. Susan Sontag, ed. New York: Farrar, Strauss and Giroux: 1976.

Augustine. City of God. Trans. Gerald Walsh, D. Zema, G. Monahan \& D. Honan; Golden City, New York: Image Books, 1958.

Augustine. Confessions. Trans. John K. Ryan. Garden City, New York: Image Books, 1960.

Bateson, Gregory. Steps to an Ecology of Mind. New York: Ballantine Books, 1972.

Bauerschmidt, Frederick C. "The Wounds of Christ." Literature and Theology 5,1/ March 1991:83-100.

Benjamin, Walter. Illuminations. Trans. Harry Zohn. New York: Schocken, 1968.

The New Oxford Annotated Bible Herbert G. May \& Bruce M. Metzger, eds. New York: Oxford University Press, 1952/71. 
Blanchet, André. La littérature et le spirituel. Paris: Aubier-Montaigne, 1960.

Blumenberg, Hans. The Legitimacy of the Modern Age. Cambridge MA: MIT Press, 1983.

Bremond, Henri. Histoire littéraire du sentiment religieux en France. (1916-1933). Paris: Armand Colin, 1967 (12 vols.)

Buber, Martin. I and Thou. (1923) Trans. Ronald Gregor Smith. New York: Collier-Macmillan, 1958.

Bultmann, Rudolf. History and Eschatology. Edinburgh: Edinburgh University Press, 1957.

Caillet, Émile. Pascal. Genius in the Light of Scripture. Philadelphia: Westminster Press, 1945.

Certeau, Michel de. La fable mystique. XVIe-XVIIe siècle. Paris: Gallimard, 1982.11

- --. Heterologies. Discourse on the Other. Trans. Brian Massumi.

Minneapolis: University of Minnesota Press/ Theory and History of Literature, vol. 17, 1986.

Crashaw, Richard. The Complete Poetry of Richard Crashaw. George Walton Williams, ed. Garden City, New York: Doubleday, 1970.

Dante, Aligheri. Divina commedia. Trans. Allen Mandelbaum. Toronto, etc.: Bantam, 1980-82.

Deleuze, Gilles \& Guattari, Félix. A Thousand Plateaus. (1980) Trans. Brian Massumi. Minneapolis: University of Minnesota Press, 1987.

Dionne, James Robert. Pascal et Nietzsche. New York: Burt Franklin, 1974.

Fletcher, F.T.H. Pascal and the Mystical Tradition. Oxford: Blackwell, 1954.

Foucault, Michel. Les Mots et les choses. Une archéologie des sciences humaines. Paris: Gallimard, 1966.

- --. Power/Knowledge. Colin Gordon, ed. Brighton: Harvester Press, 1980.

Gersh, Stephen. Middle Platonism and Neoplatonism in the Latin Tradition. Notre Dame: Un. of Notre Dame Press, 1986, vol. 1.

Goff, Jacques, le. La naissance du Purgatoire. Paris: Gallimard, 1981.

Gurevich, A. Ja. "Popular and scholarly medieval cultural traditions: notes in the margin of Jacques le Goff's book." Journal of Medieval History, 9 (1983): 71-90. 
Guyon, Jeanne de la Motte. La Vie de madame Guyon écrite par elle-même. Benjamin Sahler, ed. Paris: Dervy-Livres, 1983.

Hegel, Georg Wilhelm Friederich. Phenomenology of Spirit. (1807) Trans. A.V. Miller. Oxford, etc.: Oxford University Press, 1977.

Huxley, Aldous. Do What You Will. London: Chatto \& Windus, 1929.

---. Brave New World. London: Chatto \& Windus, 1931.

Kantorowicz, Ernst H. The King's Two Bodies. A Study in Medieval Political Theology. Princeton NJ: Princeton University Press, 1957.

Kolakowski, Leszek. Chrétiens sans Eglise. La Conscience religieuse et le lien confessionnel au XVIIe siècle (1964) French trans. Anna Posner. Paris: NRF, Gallimard, 1969.

Lubac, Henri de. Corpus mysticum. (1st ed., 1944) 2nd ed. Paris: AubierMontaigne, 1949.

Marin, Louis. Le Corps du roi. Paris: Minuit, 1981.

Marin, Louis. La Parole mangée et autres essais théologico-politiques. Paris: Méridiens - Klincksieck, 1986.

Maximus the Confessor. "Centuries." (630-634) Philokalia, II.

Mihailescu, Calin A. "Mind the Gap. Dystopia as Fiction." Forthcoming in Style 2/Summer, 1991.

Pascal, Blaise. Oeuvres complètes. Louis Lafuma, ed. Paris: 1951.

---. Pensées. Louis Lafuma, ed. Paris: Seuil, 1962.

*** Philokalia (1782) compiled by St. Nikodimos of the Holy Mountain and St. Makarios of Corinth. Trans. G.E.H. Palmer, Philip Sherrard and Kallistos Ware. London \& Boston: Faber and Faber, 1981 (3 vols.)

Plato. The Collected Dialogues. Princeton, NJ: Princeton University Press/ Bollingen Series, 1963.

Schmitz du Moulin, Henri. Blaise Pascal. Une autobiographie spirituelle. Assen: Van Gorcum, 1982.

Shestov, Lev. "Gethsemane Night; Pascal's Philosophy." In Job's Balances. On the Sources of the Eternal Truths. (1929) Trans. Camilla Coventry and C.A. Macartney. Athens: Ohio University Press, 1975:274-326.

Sloterdijk, Peter. Critique of Cynical Reason. (1983) Trans. Michael Eldred. Minneapolis: Minnesota University Press/ Theory and History of Literature, vol. 40, 1987.

Strowski, Fortunat. Pascal et son temps. Paris: Plon, 1907 (3 vols.) 
Teresa of Avila, St. The Collected Works. Trans. Kieran Kavanaugh and Otilio Rodriguez. Washington D.C.: Institute of Carmelite Studies, 1976 (3 vols.)

Wittgenstein, Ludwig. Tractatus Logico-Philosophicus. (1921) Trans. D.F. Pears \& B.F. McGuiness. London: Routledge \& Kegan Paul, 1961. 